\title{
The 9th International Conference on Geomorphology held in New Delhi, India
}

Organized by Indian Institute of Geomorphologists under the auspice of International Association of Geomorphologists (IAG), the 9th International Conference on Geomorphology (9th ICG) was held at Vigyan Bhawan, New Delhi, India on November 6th-11th, 2017. This conference attracted more than 500 participants from 47 countries and regions all over the world. The main theme of the Conference was "Geomorphology and Society", which included over 40 scientific sessions, 7 keynote lectures and a workshop devoted to Young Geomorphologists.

On the first day of the conference, the inaugural ceremony and welcome reception took place at Vigyan Bhawan in the late afternoon. Cultural programmes consisting of traditional Indian songs, dances, exciting acrobatics and musical performances were presented to the participants in the evening. On the morning of November 7th, the IAG General Assembly was held at the plenary hall of the conference venue. 22 young geomorphologists from 10 developing countries received IAG travel grants, which was a great achievement of the IAG. Prof. Morgan De Dapper from Belgium, Prof. Michael Crozier from New Zealand and Prof. Mateo Gutierrez from Spain were awarded IAG Honorary Fellow.

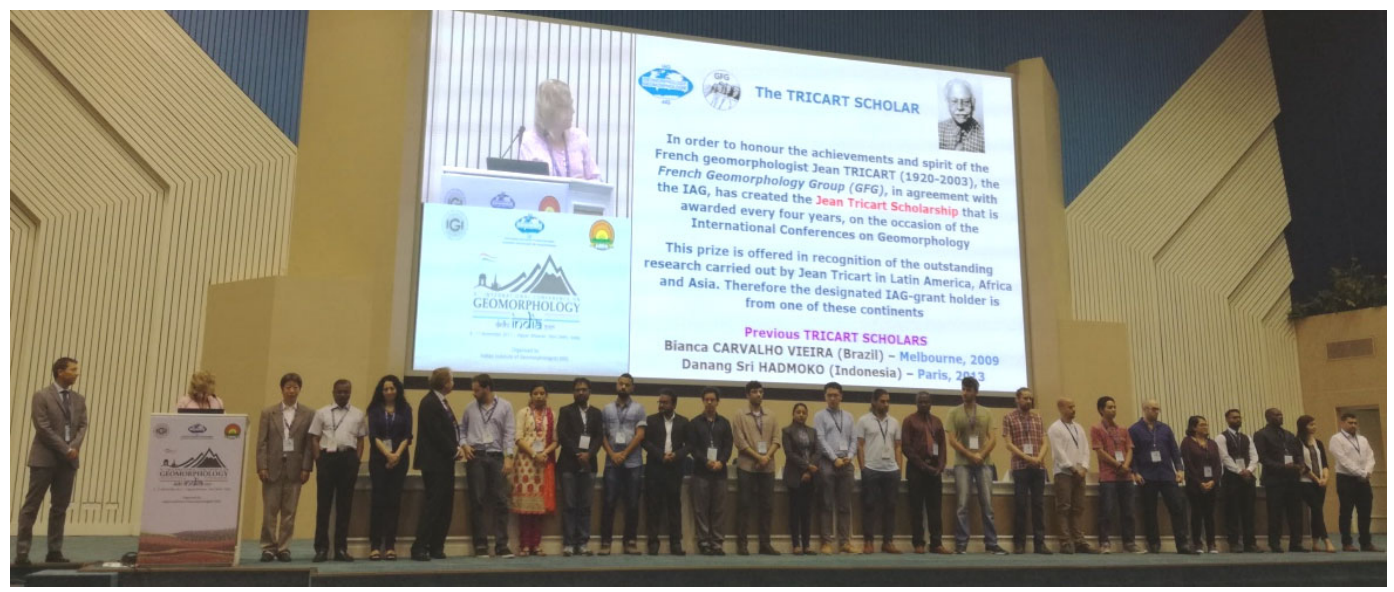

Picture: Granted young geomorphologists on the IAG General Assembly of 9th ICG

During the conference, plenary lectures were given by 7 reputed geomorphologists, which were Geomorphology and society by Prof. Michael Crozier (New Zealand), Equilibrium, evolution and least action principle; the factors controlling system self-adjustment in geomorphology by Prof. Gerald C. Nanson (Australia), Rivers in the tropics by Prof. Avijit Gupta (Australia), Geomorphological applications of GIS: historical review and future 
perspectives by Prof. Takashi Oguchi (Japan), Applied geomorphological investigations using the trenching technique. Sinkholes, faults, landslides, floods by Prof. Francisco Gutierrez (Spain), Geomorphology in India by Prof. Savindra Singh (India) and Geomorphology, disaster risk reduction and policy making: on the road to Sendai by Prof. Irasema Alcantara Ayala (Mexico).

30 Chinese participants took active part in various events and scientific sessions. 15 experts from China made a total of 16 oral presentations and some of them acted as session chairs.

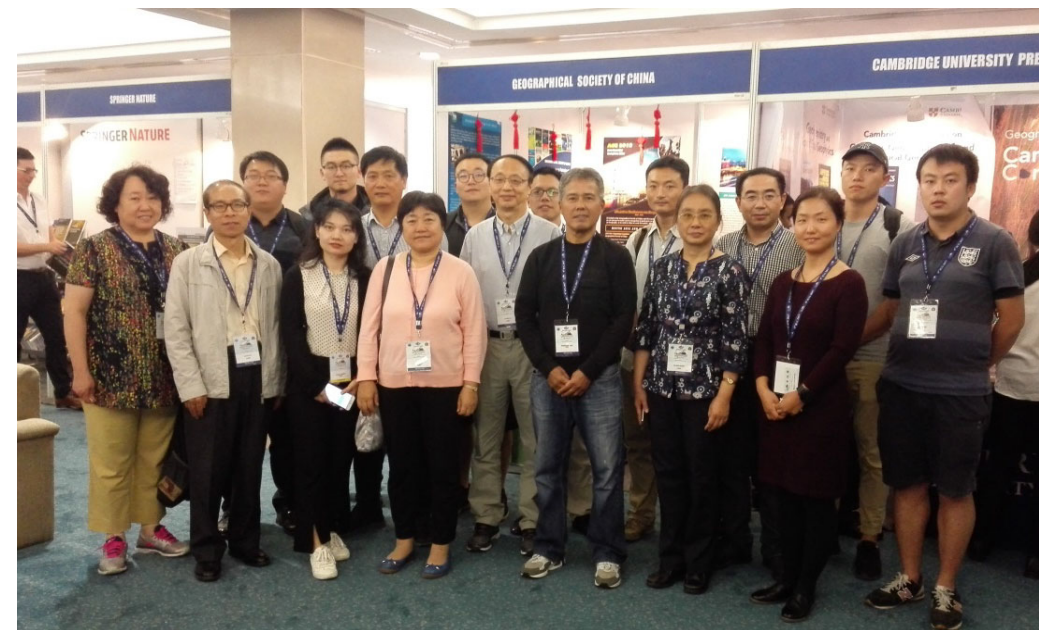

Picture: Chinese participants in front of exhibition booth of Geographical Society of China

During the IAG Council Meeting, the Executive Committee for the term of 2017-2021 was elected: Prof. Mauro Soldati from Italy as President, Prof. Sunil Kumar De from India, Dr. Susan Conway from UK, Prof. Francisco Gutierrez from Spain as Vice Presidents, Prof. Emmanuel Reynard from Switzerland as Treasurer, Dr. Mihai Micu from Romania as Secretary General, Prof. Kosmas Pavlopoulos as Publications Officer. Besides, the venues to host the upcoming IAG regional and international conferences 2017-2021 were also decided by vote: the first and the second IAG regional conferences will take place in Greece in 2019 and in Iran in 2020. The 10th International Conference on Geomorphology will be held in Portugal in 2021. At last, three new Working Groups of IAG have been approved, one of which was promoted by Chinese geomorphologist Prof. Heqing Huang.

As the official partner for the IAG on behalf of China, the Geographical Society of China actively participated in the exhibition during the 9th ICG, introducing the development achieved by Chinese geography in the past decades, showcasing English journals and representative books of Chinese geography, and promoting the 4th Asian Conference on Geography, to be held in Guangzhou in early December, 2018. Many participants showed their interests and signed for the event.

Apart from the conference, field trips have been arranged in various parts of India and neighboring countries, before, during and after the Conference, such as Deccan Plateau, Darjeeling Himalaya, Thar Desert, and Nepal Himalaya. 